\title{
Sposobnost apikalnog brtvljenja novog materijala: analiza filtracijskom tehnikom
}

\section{Apical Sealing Ability of a Novel Material: Analysis by Fluid Filtration Technique}

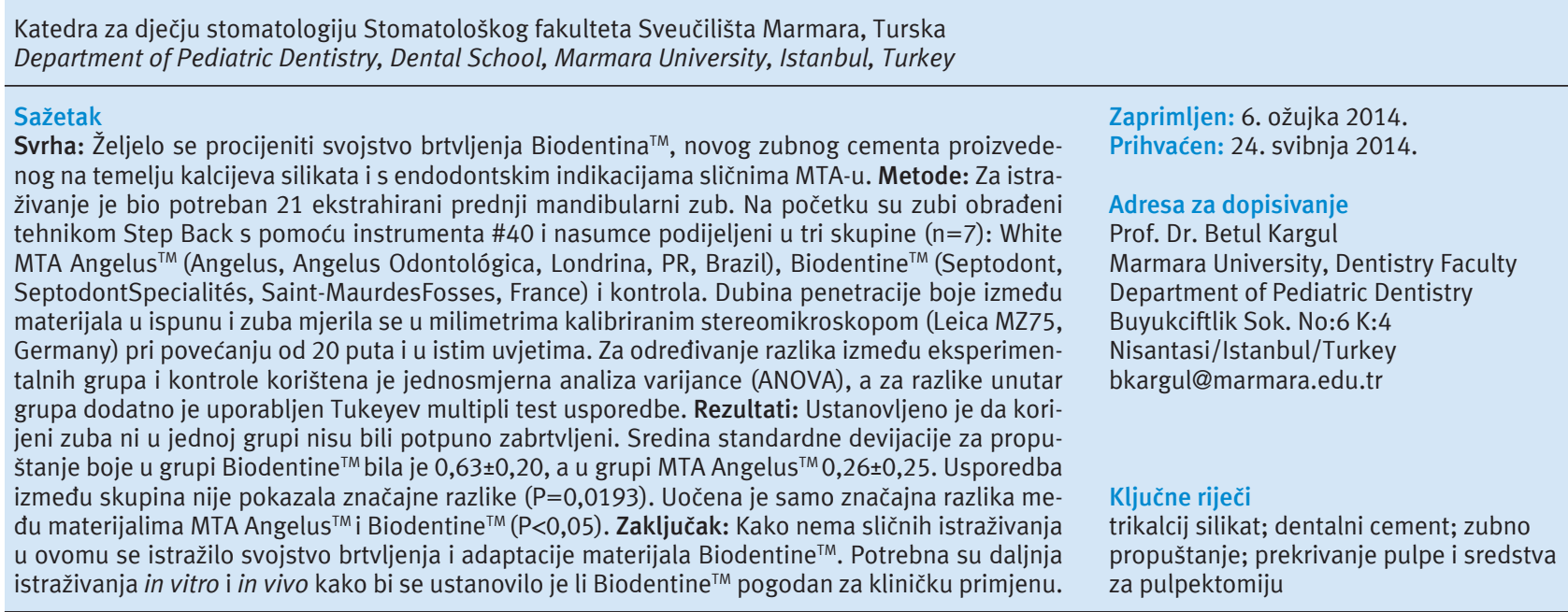

Uvod

U suvremenoj dentalnoj medicini korijenski se kanali mogu uspješno očistiti i oblikovati. I to u gotovo 90 posto slučajeva klasičnom endodontskom terapijom zbog sve boljih instrumenata i tehnika. No pritom je pojavljuje nekoliko nepovoljnih čimbenika poput perforacija, loma instrumenata, kalcifikacija i anatomskih anomalija, što sve može rezultirati neuspješnim liječenjem. Katkad klasična endodontska terapija nije dovoljna za rješavanje problema i potrebna je endodontska kirurgija $(1,2)$.

Endodontska terapija završava trodimenzionalnim punjenjem sustava korijenskog kanala materijalom zadovoljavajućih fizikalnih i bioloških svojstava $(3,4)$. Materijal za punjenje trebao bi primjereno brtviti i istodobno spriječiti ulazak fluida u prostor kanalnog sustava, stimulirati cijeljenje periapikalnih patologija i potaknuti odlaganje korijenskog cementa za postizanje biološkog brtvljenja $(5,6,7)$. Materijal za brtvljenje, pak, trebao bi ispunjavati nekoliko zahtjeva poput biokompatibilnosti, antibakterijskih svojstava, dimenzijske stabilnosti, radiokontrasnosti, lakoće rukovanja, netopivosti u tjelesnim tekućinama, adaptabilnost na stijenke kanala (8) te lakoću stvaranja hermetičnog brtvljenja. Ni jedan

\section{Introduction}

In modern dentistry, cleaning and shaping of the root canal system can be efficiently performed. Due to improvements on instruments and techniques, it is now possible to obtain a success rate of nearly $90 \%$ with conventional root canal therapy. However, several factors inherent to the endodontic procedures, such as perforations, instrument breakage, calcifications and anatomic anomalies can lead to treatment failure. In some cases, conventional endodontic treatment is not sufficient to solve the problem and a surgical endodontic intervention is required $(1,2)$.

Endodontic obturation comprises complete three-dimensional filling of the root canal system with materials that exhibit satisfactory physical and biological properties $(3,4)$. Ideally, the filling material should adequately seal the root canal and simultaneously prevent fluid percolation into the root canal space, stimulate the resolution of periapical pathologies, and encourage deposition of cementum to achieve biological seal $(5,6,7)$.

Filling materials should meet several requirements, such as biocompatibility, antibacterial properties, dimensional stability, radiopacity, ease of manipulation, insolubility in 
od trenutačno dostupnih materijala nema sva svojstva potrebna za idealni materijal za brtvljenje $(9,10)$. Svake godine proizvede se mnogo novih materijala za punjenje korijenskih kanala (11), ali ni jedan nije bolji od gutaperke u kombinaciji s cementom $(12,13)$.

U dentalnoj medicini kalcijevi silikati testirani su za terapiju dentinske preosjetljivosti i obećavaju u endodonciji (13). Najpoznatiji cement na toj osnovi i dalje je mineral-trioksid-agregat (MTA) koji se pojavio na tržištu 1993. (14), a rabi se pri terapiji perforacija korijena te za retrogradna punjenja i zatvaranje otvorenih apeksa mladih zuba. U trima izvrsnim preglednim radovima opisana su njegova fizikalna i bakteriološka svojstva (15), biokompatibilnost i mogućnost brtvljenja (12) te način djelovanja (16). U tvornici Angelus Soluçóes Odontológicas predstavili su 2001. godine MTA razvijen u Brazilu koji je navodno identičan onome razvijenom u Torabinejadu $(17,18)$. Odnedavno se biološka svojstva MTA nastoje uklopiti u materijal kojim će se lako raditi pa su proizvođači u cemente na osnovi MTA dodali razne specifične spojeve (3).

Prah Biodentine ${ }^{\mathrm{TM}}$ uglavnom se sastoji od trikalcijeva silikata, kalcijeva karbonata i cirkonijeva oksida - to je osnova u koju je kao tekućina dodan kalcijev klorid za što brže stvrdnjavanje te sredstvo za istiskivanje vode (19). Biodentine ${ }^{\mathrm{TM}}$ stvara apatit nakon uranjanja u fosfatnu otopinu, što je važno za njegovu bioaktivnost (20). Ovaj materijal ima ista biološka svojstva kao MTA i može biti u neposrednom doticaju sa zubnom pulpom (19) premda ga slaba otpornost na abraziju čini lošom zamjenom za caklinu $(20,21,22,23)$.

U dostupnoj literaturi nema mnogo podataka o istraživanjima fizikalnih i kemijskih svojstava Biodentina ${ }^{\mathrm{TM}}$ i o tome kako taj materijal brtvi $(24,25,26)$. Zato je svrha ovog rada bila, metodom prodora fluida tijekom 48 sati, analizirati mogućnost brtvljenja Biodentina ${ }^{\mathrm{TM}} \mathrm{i}$ usporedba s konvencionalnim MTA-om i Angelusom ${ }^{\mathrm{TM}}$.

\section{Materijali i metode}

\section{Odabir i priprema uzoraka}

Uzorak za istraživanje sastojao se od 21 izvađenog prednjeg maksilarnog zuba. Dobiveni su iz banke zuba Department of Oral Surgery Department. Isključeni su oni s višestrukim kanalima, resorpcijama, napuklinama, frakturama, kalcifikacijama u kanalu, vanjskim resorpcijama i/ili nezavršenom formacijom apeksa. Radi dezinfekcije svi su bili pohranjeni u 10-postotnom formalinu i zatim stavljeni u normalnu slinu da bi se održala vlažnost prije provedbe eksperimenta.

Kliničke krune uklonjene su rezom na cementnocaklinskom spoju, dijamantnom pločom (Buehler isomet ${ }^{\mathrm{TM}} 1000$, Njemačka) montiranom na laboratorijski motor i kontinu- oral fluids, and adaptability to the root canal walls (8) as well as the ability to produce a hermetical seal. However, none of the currently available materials feature all the characteristics of the ideal sealer $(9,10)$.

Every year, a great number of new endodontic filling materials are developed (11) but none of these materials have presented better results than the association of gutta-percha with conventional sealers $(12,13)$.

In dentistry, calcium silicates have been tested for treatment of dentin hypersensitivity and gave promising results in endodontics (13). However, the most famous calcium silicate cement remains the mineral trioxide aggregate. MTA was introduced in 1993 (14) and is designed for root-perforation treatment, retrograde filling, and open-apex closure on immature teeth. Three excellent reviews have described the physical and bacteriological properties, (15) the leakage and biocompatibility investigations (12) and the mechanisms of action (16) of MTA. In 2001, the company Angelus Soluçôes Odontológicas introduced the MTA developed in Brazil, which is apparently identical to the MTA developed by Torabinejad $(17,18)$. More recently, in an effort to incorporate the desirable biological properties of MTA into an easy to manipulate and to insert material, the manufacturer has added specific components to MTA-based cements. (3)

Biodentine ${ }^{\mathrm{TM}}$ powder is mainly composed of tricalciumsilicate, calcium carbonate and zirconium oxide as the radiopacifier, whilst its liquid contains calcium chloride as the setting accelerator and water reducing agent (19). Biodentine ${ }^{\mathrm{TM}}$ shows apatite formation after immersion in phosphate solution, indicative of its bioactivity (20).

This material exhibits the same excellent biological properties as MTA and can be placed in direct contact with dental pulp (19) although its sensitivity to abrasion makes it a poor enamel substitute $(20,21,22,23)$.

Presently, the literature is scarce on studies evaluating the physical and chemical properties of

Biodentine ${ }^{\mathrm{TM}}$ as well as on the sealing ability of this cement $(24,25,26)$. Therefore, the objective of the present study was to analyse the sealing ability of Biodentine ${ }^{\mathrm{TM}}$, while simultaneously comparing the performance of this material with conventional MTA Angelus ${ }^{\mathrm{TM}}$ by the fluid filtration method at observation periods of 48 hours.

\section{Material and methods}

\section{Specimen selection and preparation}

The study sample comprised 21 extracted maxillary anterior teeth. The teeth were procured from tooth bank at the Department of Oral Surgery Department. Teeth with multiple canals, resorptions, cracks, fractures, canal calcification, external root resorption and/or incomplete apex formation were excluded from the sample.

For disinfection, the specimens were stored in $10 \%$ formalin and then placed in normal saline kept moist before the experiment.

The clinical crowns were removed by sectioning at the cementum-enamel junction using a low-speed diamond saw (Buehler isomet ${ }^{\mathrm{TM}}$ 1000, Germany) attached to laboratorial 
irano hlađene zrakom/vodenim sprejom. Tako su dobiveni standardizirani korijeni od $16 \mathrm{~mm}$.

Nakon toga svaki je rendgenski snimljen kako bi se mogla procijeniti njegova anatomija i apikalna morfologija.

\section{Priprema korijena}

Prohodnost kanala ispitana je ručnim K-instrumentom \#15 (Dentsply, Dentsply/Maillefer, Ballaigues, Švicarska). Uzorci su numerirani, a njihove dužine određene su ručno uvođenjem instrumenta \#15 dok njegov vrh nije dotaknuo apikalni foramen.

Pri svakoj promjeni instrumenta kanali su isprani s 1,0 $\mathrm{mL} 2$ 2,5-postotne otopine $\mathrm{NaOCl}-\mathrm{a}$ (Hyposol, Sodium Hypochloride, Indija). Nakon konačne irigacije $\mathrm{NaOCl}$-om $(1,0 \mathrm{~mL}$ ), kanal je ispran s 5,0 mL fiziološke otopine (Isotonic sodium chloride, Eczacıbası, Turska). Uzorci su zatim StepBack tehnikom obrađeni čeličnim nehrđajućim instrumentima do instrumenta \#40 (Dentsply, Dentsply/Maillefer, Ballaigues, Švicarska). Kanali su na kraju irigirani s 20 mL 0,5-postotne otopine $\mathrm{NaOCl}-\mathrm{a}$ (Hyposol, Sodium Hypochloride, Indija).

Prije punjenja korijenskih kanala apikalni krajevi odrezani su pod neprekidnim hlađenjem (zrak/vodeni sprej) dijamantnim svrdlom \# 4138 (Dentsply Dentsply/Maillefer, Ballaigues, Švicarska) $2 \mathrm{~mm}$ od apeksa pod kutom od $90^{\circ}$. Radi standardizacije uzoraka radna duljina usklađena je na $16 \pm 1 \mathrm{~mm}$.

Korijenski kanali osušeni su papirnatim šiljcima (Absorbent, Paper Point, Koreja) te napunjeni tehnikom lateralne kondenzacije.

Uzorci su pohranjeni 15 dana na temperaturi od $37^{\circ}$ $\mathrm{C}$ radi inhibicije filtracije tekućine i dehidracije. Zatim su nasumce podijeljeni u dvije eksperimentalne grupe $(n=14)$ i jednu kontrolnu ( $n=7)$. Grupe su zatim podijeljene u podgrupe od po sedam zuba, ovisno o korištenom materijalu.

\section{Postupak punjenja vrha korijena}

U grupi White MTA Angelus ${ }^{T M}$ (Angelus, Angelus Odontológica, Londrina, PR, Brazil), materijal je, prema uputama proizvođača, pripremljen miješanjem u omjeru 1:1 (prah : sterilna voda) i pri malim okretajima Lentulove spirale (Dentsply-Maillefer Instruments SA, Ballaigues, Švicarska) unesen $3 \mathrm{~mm}$ kraće od apikalnog foramena. MTA je apikalno kondenziran instrumentom ISO $\mathrm{K} \# 90$ umotanim u vatu. Drugi K-instrument $s$ navlaženom vatom korišten je za uklanjanje viška MTA s dentinskih stijenki. U slučaju prepunjenja korijena višak materijala također je uklonjen.

U grupi Biodentine $^{\mathrm{TM}}$ (Septodont, Septodont Specialités, Saint-Maur des Fosses, Francuska) materijal je pripremljen prema uputama proizvođača miješanjem triju doza praha $s$ jednom kapi fiziološke otopine te pri malim okretajima Lentulove spirale (Dentsply-Maillefer Instruments SA, Ballaigues, Švicarska) unesen u kanal kao i MTA Angelus ${ }^{\mathrm{TM}}$. Postupak kondenzacije i uklanjanja viška obavljen je također kao pri MTA.

U kontrolnoj grupi uzorci uopće nisu bili napunjeni. handpiece under continuous air/water spray to create a standardized root length of $16 \mathrm{~mm}$.

Each root was submitted to radiographic examination to evaluate anatomy and apical morphology.

\section{Root preparation}

The canals were initially explored using \#15 hand-held K-files (Dentsply, Dentsply/Maillefer, Ballaigues, Switzerland). Subsequently, teeth were numbered and their real canal lengths were determined by manually inserting \#15 Kfiles into the canals, until the instrument tips were visible at the apical foramen.

At each file change, canals were irrigated with $1.0 \mathrm{~mL}$ of $2.5 \% \mathrm{NaOCl}$ (Hyposol, Sodium Hypochloride, India). Afterwards, a final flush with $1.0 \mathrm{~mL}$ of $\mathrm{NaOCl}$ followed by 5.0 $\mathrm{mL}$ of saline (Isotonic sodium chloride, Eczacıbası, Turkey) was performed. Specimens were instrumented up to stainless steel files size of \#40 (Dentsply, Dentsply/Maillefer, Ballaigues, Switzerland) following the stepback technique, and after that the canals were irrigated with $20 \mathrm{~mL}$ of $0.5 \% \mathrm{NaOCl}$ solution (Hyposol, Sodium Hypochloride, India).

Before obturating the canals, apical ends were cut $2 \mathrm{~mm}$ from the dental apex at angles of $90^{\circ}$ using a \#4138 diamond-coated bur (Dentsply, Dentsply/Maillefer, Ballaigues, Switzerland) under continuous air/ water spray. Working root canal length was established $16 \pm 1 \mathrm{~mm}$ in order to standardize all specimens.

The root canals were dried with paper points (Absorbent, Paper Point, Korea) and filled using the lateral condensation technique.

At that point, the samples were stored at $37^{\circ} \mathrm{C}$ for 15 days for inhibition of liquid infiltration and dehydration. Samples were randomly placed into two study experimental groups ( $\mathrm{n}=14)$ and control group $(\mathrm{n}=7)$. The groups were further divided into subgroups of 7 teeth each, according to the materials.

\section{Root-end filling procedures}

In the group White MTA Angelus ${ }^{\mathrm{TM}}$ (Angelus, Angelus Odontológica, Londrina, PR, Brazil), the material was prepared following the manufacturer's instructions, mixed at a 1:1 ratio (powder: sterile water) and applied with a Lentulo spiral (Dentsply-Maillefer Instruments SA, Ballaigues, Switzerland) at low speed up to $3 \mathrm{~mm}$ short of the apical foramen. The MTA was condensed up to the apical end with an ISO K file \# 90 wrapped in cotton. Another K file wrapped in moistened cotton was used to remove the excess MTA from the dentin walls. The MTA was condensed up to the apical end with aid of an ISO 90 K-file wrapped in cotton. Another K-file wrapped with moistened cotton was used to remove the excess MTA from the dentinal walls. In case of overfilling, the excess material was also removed.

In group Biodentine ${ }^{\mathrm{TM}}$ (Septodont, Septodont Specialités, Saint-Maur des Fosses, France), the material was also prepared according to the manufacturer's instructions, mixed at three portions of powder and one drop of saline solution, and applied with a Lentulo spiral (Dentsply-Maillefer Instruments SA, Ballaigues, Switzerland) in low speed as described 
Učinjena su tri radiograma u različitim fazama pripreme uzoraka: pri odabiru uzoraka, tijekom endodontskog postupka i nakon njegova završetka.

\section{Tehnika fluidne infiltracije}

Koronarni otvor zatvoren je ljepljivim voskom (Cavex, modelling wax, Nizozemska), a zatim su vanjske površine korjenova iz eksperimentalnih i kontrolne grupe prekrivene dvama slojevima laka za nokte (Flormar, Turska), osim područja od 1,0 mm oko apeksa korijena. Uzorci u kontrolnoj grupi cijeli su premazani, ali ne i vrh korijena.

Curenje se procjenjivalo tehnikom infiltracije fluida koju su opisali Vasconcelos i njegovi suradnici (3).

Uzorci iz svih grupa stavljeni su 48 sati u bazični fuksin na sobnoj temperaturi. Na bukalnim i palatinalnim stranama zuba učinjeni su vertikalni urezi, a zubi su uzdužno prerezani dijamantnim nožem od 12,7 mm (Buchler, Germany) hlađenim vodom. Dužina prodiranja boje između materijala za punjenje i zubne strukture mjerila se u milimetrima kalibriranima stereomikroskopom (Leica MZ75, Njemačka) pri povećanju od 20 puta i u istim uvjetima. Tri neovisna promatrača mjerila su linearnu penetraciju boje tri puta u istim uvjetima; za dubinu penetracije boje svakog uzorka odabrana je aritmetička sredina svih mjerenja jednog uzorka.

\section{Statistička analiza}

Statistička analiza obavljena je paketom SPSS software verzija 16,0 Windows (SPSS Inc., Chicago, IL, SAD). Kvantitativne vrijednosti određene su kao aritmetičke sredine \pm standardna devijacija (SD). Kako bi se pronašle razlike između eksperimentalnih i kontrolne grupe, korištena je jednosmjerna analiza varijance (ANOVA), a za razlike unutar svake grupe dodatno je upotrebljen Tukeyev višestruki usporedni test.

\section{Rezultati}

Kod svih uzoraka u eksperimentalnim grupama zabilježena je određena količina apikalnog curenja. Na temelju testa prodiranja boje zaključeno je da ni jedan uzorak nije bio potpuno zabrtvljen. Mikroskopske slike ostalih četiriju grupa nalaze se na slici 1 . i tablici 1 . na kojoj su i vrijednosti mikrocurenja svake grupe.

Uspoređujući grupe međusobno, ustanovljena je značajna razlika $(\mathrm{P}=, 0193)$. Zubi punjeni MTA Angelusom ${ }^{\mathrm{TM}}$ imali su manje vrijednosti curenja negoli Biodentine ${ }^{\mathrm{TM}}$. Pronađena je statistički značajna razlika $(\mathrm{P}, 05)$ u količini mikrocurenja kod obaju biomaterijala. for MTA Angelus ${ }^{\mathrm{TM}}$. The condensation and excess removal was performed as described for the MTA.

In the control group, samples were not obturated with any material.

Three radiographs were taken at different stages of specimen preparation: on sample selection; during endodontic treatment and after treatment.

\section{Fluid Infiltration Technique}

The coronal access of the specimens was sealed with sticky wax (Cavex, modelling wax, Netherlands). After this period, the external root surfaces of the specimens in the experimental and the control groups were completely covered by two coats of nail varnish (Flormar, Turkey), except for an area of $1.0 \mathrm{~mm}$ around the root apex. The specimens in the control group had their root surfaces completely covered, but without root end.

Leakage was evaluated by the fluid infiltration technique as described by Vasconcelos et al. (3).

The specimens from all groups were placed in basic fuchsine for 48 hours at room temperature. Vertical grooves were cut on the buccal and palatal aspects of all the specimens, and the teeth were longitudinally sectioned by $12.7 \mathrm{~mm}$ diamond water in blade (Buchler, Germany). The length of dye penetration between the filling material and tooth structure was measured separately in millimetres, using a calibrated stereomicroscope (Leica MZ75, Germany) at $20 \times$ magnification under same conditions. Linear dye penetration was measured independently by three observers at three different times under the same conditions; the mean value of the recorded measurements was chosen as the extent of dye penetration into each specimen.

\section{Statistical Analysis}

Statistical analysis was performed by SPSS software package, Version 16.0 for Windows (SPSS Inc., Chicago, IL, USA). Quantitative values are presented as mean \pm standard deviation (SD). One-way Analysis of Variance (ANOVA) was used to indicate differences between the experimental groups and the control. In addition, Tukey Multiple Comparisons Test was used to indicate differences within each group.

\section{Results}

all samples in the experimental groups demonstrated variable amounts of apical leakage. Based on dye penetration results, they were not completely sealed in any of the groups.

The microscopic photographs of other four groups are presented in Figure 1, whereas Table 1 shows microleakage values for each group.

Regarding the comparisons between each group, significant differences were observed $(\mathrm{P}=0.0193)$. Teeth filled with MTA AngelusTM showed lower leakage values than BiodentineTM. A statistically significant difference $(\mathrm{P}<0.05)$ was observed between the various amounts of microleakage in teeth with both biomaterials. 

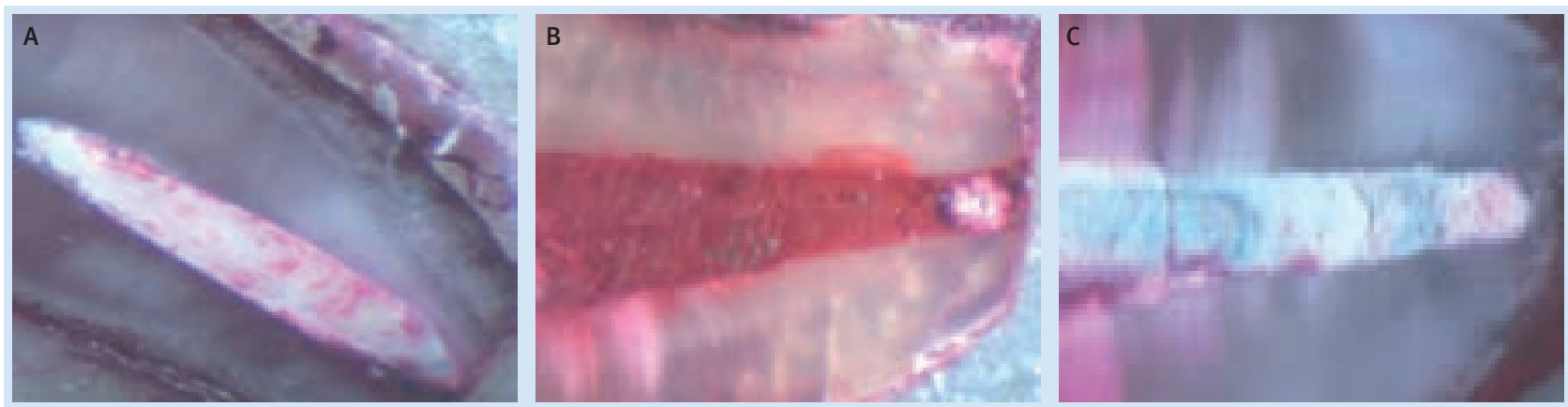

Slika 1. Stereomikroskopska fotografija kontrolne i eksperimentalne skupine; A: Penetracija između zubnih struktura i Biodentina ${ }^{\mathrm{TM}}$; B: Penetracija u kontrolnoj skupini; C: Penetracija između zubnih struktura i MTA Angelusa ${ }^{\text {TM }}$

Figure 1 The Stero microscoph photography of control and experimantal groups; A: The view of dye Penetration between dental structure and Biodentine ${ }^{\mathrm{TM}} ; \mathrm{B}$ : The view of dye Penetration of control group; C: The view of dye Penetration between dental structure and MTA Angelus ${ }^{\mathrm{TM}}$

Tablica 1. Aritmetičke sredine i median-vrijednosti curenja te standardne devijacije za Biodentine ${ }^{\mathrm{TM}}$ i MTA Angelus ${ }^{\mathrm{TM}}$

Table 1 The mean and median leakage values, and standard deviations for Biodentine TM and MTA AngelusTM

\begin{tabular}{l|c|c} 
& $\begin{array}{c}\text { Artit. sredina } \pm \text { SD } \mathbf{~ m m} \\
\text { Mean } \pm \text { SD mm } \\
\mathbf{N}=7\end{array}$ & Median \\
\hline Biodentine $^{\mathrm{TM}}$ & $0.63 \pm 0.20$ & 0.63 \\
\hline MTA Angelus $^{\mathrm{TM}}$ & $0.26 \pm 0.25$ & 0.19 \\
\hline Control $^{\mathrm{T}}$ & $0.46 \pm 0.19$ & 0.41
\end{tabular}

\section{Rasprava}

Hermetičkim brtvljenjem i potpunim punjenjem korijenskog kanala smanjuje se mogućnost da će mikroorganizmi zaostali u kanalu, u kontaktu s oralnim ili periapikalnim fluidima, imati izvor hrane. To može biti razlog za neuspjeh endodontske terapije čak i nekoliko godina nakon njezina završetka (20). Zbog toga su istraživanja o curenju prijeko potrebna za procjenu različitih čimbenika uključenih u postupak punjenja korijenskog kanala.

Predloženo je nekoliko metodologija za procjenu brtvljenja materijala za punjenje, uključujući propuštanje bakterija, ljudsku slinu, proteinske komplekse, fluidne filtracije i propuštanje boje $(27,28)$. Najčešće je u primjeni test prodiranja boje i bakterijskog curenja (29). Metoda prodora boje kvalitativna je i destruktivna po prirodi, tako da je nemoguća longitudinalna procjena mikrocurenja. Dokazano je također da alkalni materijali uzrokuju diskoloraciju metilenskog modrila, što može rezultirati nepouzdanim zaključcima u testu penetracije boje (30).

Najprihvatljivija metoda trenutačno je fluidna filtracija koju su opisali Derkson i suradnici.

(31). Njezina glavna prednost je u tome što se mogu sačuvati uzorci nakon svakog mjerenja, pa je moguća analiza različitih razdoblja istraživanja. Ova metoda dokazano je osjetljiva i reproducibilna (3).

Od boja se rabi metilensko modrilo u različitim koncentracijama (28). Wu i suradnici (32) proveli su zanimljivo istraživanje u kojem tvrde da metilensko modrilo uzrokuje diskoloraciju ako dolazi u doticaj s alkalnim tvarima za punjenje, a to može rezultirati netočnim podatcima za takve materijale u istraživanjima propusnosti. Metilenska diskoloracija događa se zbog njezine nestabilnosti u doticaju s alkalnim tvarima. Takvi materijali uzrokuju hidrolizu metilenskog modrila, pa nastaje bistra tvar zvana tionin. To bi moglo

\section{Discussion}

Achieving a hermetic seal by entirely filling the root canal space decreases the risk that microorganisms left in the canal might come in contact with oral or periapical fluids, a potential source of nutrition. This could lead to failure of endodontic therapy, even years after the treatment is completed (20). Based on these facts, leakage studies are of crucial importance to evaluate the different factors involved in the process of root canal obturation.

Several methodologies have been proposed to establish the sealing ability of filling materials, including evaluation of leakage of bacteria, human saliva, protein complex, fluid filtration and dye leakage $(27,28)$.

Dye penetration and bacterial leakage are more widely used (29). The dye penetration method is qualitative in nature and also destructive, therefore a longitudinal evaluation of microleakage is impossible. In addition, it was shown that alkaline materials cause methylene blue discoloration, which may lead to unreliable conclusions in dye penetration tests (30).

Currently, the most widely accepted method is fluid filtration, proposed by Derkson et al. (31). The main advantage of the fluid filtration technique is the possibility of preserving the specimens after each assay, allowing analysis at different study periods. Moreover, this method has proven to be sensitive and reproducible (3).

Among the dyes, use of methylene blue at different concentrations has been outstanding (28). However, Wu et al. (32) conducted an interesting study and stated that methylene blue suffers discoloration when in contact with some alkaline filling materials, which may cause unrealistic results of such materials in leakage studies. Methylene blue discoloration occurs because it is unstable when in contact with alkaline materials. Such materials cause hydrolysis of methylene 
objasniti zašto metilensko modrilo gubi boju u kontaktu $s$ kalcijevim hidroksidom.

U odnosu na MTA, u prisutnosti vode, kalcijev oksid bi u materijalu mogao stvoriti kalcijev hidroksid koji bi sigurno uzrokovao gubitak boje metilenskog modrila $(32,33,34)$.

Iz navedenih razloga u ovom je istraživanju o svojstvima brtvljenja MTA Angelusa ${ }^{\mathrm{TM}}$ kod provođenja testa propuštanja korišten bazični fuksin umjesto metilenskog modrila, a na temelju rezultata u navedenim istraživanjima (35).

Zbog ograničenja u istraživanju prodora boje, propuštanje se mjeri samo u jednoj prerezanoj ravnini, što onemogućuje procjenu ukupne količine curenja (36).

$\mathrm{U}$ ovom istraživanju procijenjeno je svojstvo brtvljenja Biodentina ${ }^{\mathrm{TM}}$, biomaterijala koji se primjenjuje u kliničkoj praksi jer nema mnogo istraživanja u kojima se proučavalo kako djeluje.

$\mathrm{U}$ ovom istraživanju uspoređeno je svojstvo brtvljenja dvaju materijala za punjenje korijenskih kanala. Dobiveni rezultati pokazuju da bijeli MTA manje propušta negoli Biodentine $^{\mathrm{TM}}$, bez obzira na debljinu, promjer apikalnog foramena ili proteklo vrijeme.

U nekoliko istraživanja uspoređivala su se metodom fluidne filtracije dva eksperimentalna materijala za punjenje korijenskog kanala. U nekoliko studija istaknuto je da MTA značajno manje curi negoli ostali materijali $(36,37)$.

MTA je bolji jer manje propušta od ostalih materijala za punjenje korijena $(17,36)$, ali ima i druga povoljna svojstva poput lakog rukovanja, biokompatibilnosti, a tu je i veća tolerancija pri korištenju (3).

Izvrsna svojstva brtvljenja sivog MTA-Angelusa ${ }^{\mathrm{TM}}$ potvrdili su mnogi istraživači $(18,19,28,36)$, no Silva Neto i suradnici u svojoj ga studiji ne smatraju dobrim materijalom (38).

Istraživanja sposobnosti brtvljenja i dalje su važna u endodonciji, posebno kao početne postavke za novostvorene materijale. Budući da je MTA u mnogim istraživanjima svrstan u materijale s dobrim svojstvima brtvljenja $(39,40,41$, 42), važno je da novi materijali u endodonciji budu barem slični ili da još bolje sprječavanju curenje. Mehanizam koji omogućuje MTA-u nadmoć u brtvljenju nije do kraja objašnjen. Analizom doticaja MTA sa sintetskim tkivnim fluidom i korijenskim dentinom, Sarkar i suradnici (43) smatraju da MTA na početku mehanički brtvi ali se daljnjim otapanjem stvaraju kristali hidroksiapatita koji reagiraju s dentinom i stvaraju kemijsku adheziju (43). Tay i suradnici (44) nisu uspjeli potvrditi slične rezultate $\mathrm{u}$ istraživanju curenja na vrhu korijena punjenog bijelim MTA-om. Možda se značajna razlika nije mogla pronaći zbog velike standardne devijacije dobivene u grupi s bijelim MTA-om (45).

Prema podatcima proizvođača, Biodentin ${ }^{\mathrm{TM}}$ ima slična ili bolja fizikalna, kemijska i biološka svojstva u usporedbi s MTA-om u istim kliničkim indikacijama. Budući da je i ovaj materijal mineral-trioksid-agregat, u ovom istraživanju procijenjeno je eventualno korištenje apikalnog čepa te njegove mogućnosti brtvljenja i marginalne adaptacije. To je učinjeno zato što nije pronađena ni jedna informacija u literaturi $\mathrm{u}$ vezi sa svojstvom brtvljenja Biodentina ${ }^{\mathrm{TM}}$. Protok vremena također poboljšava brtvljenje endodontskih materijala. Ubr- blue, resulting in formation of a clear compound named thionine. This would explain why methylene blue is discoloured by calcium hydroxide.

Regarding MTA, in the presence of water, the calcium oxide in the material could form calcium hydroxide, which would certainly cause discoloration of methylene blue $(32,33,34)$.

Therefore, when performing the leakage test to assess the sealing ability of MTA Angelus ${ }^{\text {TM }}$, in this study, basic fuchsine was selected instead of methylene blue, based on the previously mentioned studies (35).

The limitation of dye leakage studies is that they measure the degree of leakage in only one plane, making it impossible to evaluate the total amount of leakage (36).

This study evaluated the sealing ability of Biodentine ${ }^{\mathrm{TM}}$ and the biomaterials commonly used in clinical practice. However, not many studies have demonstrated this empirically.

The present study compared the sealing ability of two root canal filling materials. The findings show that white MTA had less leakage than Biodentine ${ }^{\mathrm{TM}}$ regardless of thickness, apical foramen diameters, or the passage of time.

There are a few studies that have assessed the leakage of two experimental root-filling cements using fluid filtration method. Several studies have indicated that MTA exhibits significantly lesser leakage than other materials $(36,37)$.

MTA yields better results because it produces less leakage than other materials used in root-end filling $(17,36)$, however MTA has other beneficial properties, such as easy handling, biocompatibility and lack of technical sensitivity (3).

The excellent sealing ability of grey MTA-Angelus ${ }^{\mathrm{TM}}$ has been highlighted by several authors $(18,19,28,36)$. Conversely, in a study by Silva Neto et al., (38) MTA was not considered a good sealer.

Sealing ability studies are still important in endodontics, especially as an initial screening for newly developed filling materials. Because MTA is ranked with good sealing ability results in several studies, $(39,40,41,42)$ it is important that new endodontic materials display at least similar or better ability to prevent leakage as MTA. The mechanism that provides MTA with superior sealing ability results is not completely understood. Analysing the contact of MTA with a synthetic tissue fluid and root dentine, Sarkar et al. (43) suggested that MTA initially produced a mechanical seal and further dissolved leading to the formation of hydroxyapatite crystals, which reacted with dentine to create a chemical adhesion (43). However, Tay et al. (44) were unable to verify similar root-end filling leakage results with White MTA. Still, it is possible that a significant difference could not be detected by the statistical model owing to the elevated standard deviation displayed by the white MTA group (45).

Regarding Biodentine ${ }^{\mathrm{TM}}$, according to the manufacturer, this material has similar or better physical, chemical and biological characteristics compared to MTA, with the same clinical indications. Since this material is also a mineral trioxide aggregate, this study evaluated the possibility of using it as apical plug, as well as its sealing ability and marginal adaptation, because no previous information was found in the liter- 
zo nakon miješanja čestice kalcijeva silikata u Biodentinu ${ }^{\mathrm{TM}}$, poput svih kalcijevih silikata, reagiraju s vodom i stvaraju otopinu visokoga $\mathrm{pH}$ is $\mathrm{Ca} 2+, \mathrm{OH}$ - te silikatnim ionima. U zasićenom sloju hidrogel kalcijeva silikata precipitira na čestice cementa i počinje se stvarati kalcijev hidroksid (46). Hidrogel kalcijeva silikata s vremenom polimerizira i stvara čvrstu mrežu, a otpuštanje kalcijeva hidroksida povećava alkalnost okoliša. Slina i druge tjelesne tekućine sadržavaju ione fosfata (47) pa nastaje interakcija između fosfatnih iona i tekućine za skladištenje, što kod cemenata na bazi kalcijeva hidroksida rezultira stvaranjem nakupina apatita i može poboljšati svojstvo materijala (48).

O Biodentinu ${ }^{\mathrm{TM}}$, osim znanstvenog materijala proizvodača, malo je podataka u literaturi o njegovu korištenju kao endodontskog materijala. Uz ograničenja ovoga istraživanja in vitro može se zaključiti da MTA manje curi u usporedbi

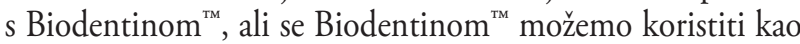
alternativnim materijalom za endodontska liječenja. Potrebna su daljnja istraživanja in vitro i in vivo kako bi se odredila svojstva brtvljenja Biodentina ${ }^{\text {TM }}$ i potvrdili naši rezultati. ature regarding the sealing ability of Biodentine ${ }^{\mathrm{TM}}$. The lapse of time also improves sealability of endodontic biomaterials.

Just after mixing, the calcium silicate particles of Biodentine, like all calcium silicate materials, react with water to form a high-pH solution containing $\mathrm{Ca} 2+, \mathrm{OH}-$, and silicate ions. In the saturated layer, the calcium silicate hydrate gel precipitates on the cement particles, whereas calcium hydroxide nucleates (46). The calcium silicate hydrate gel polymerizes over time to form a solid network, while the release of calcium hydroxide increases the alkalinity of the surrounding medium. Saliva, like other body fluids, contains phosphate ions; (47) an interaction between the phosphate ions of the storage solution and the calcium silicate-based cements leads to the formation of apatite deposits that may increase the sealing efficiency of the material (48).

Since the introduction of Biodentin ${ }^{\mathrm{TM}}$ the literature has been scarce apart from manufacturers' scientific files on its use as endondontic material. Within the limitations of this in vitro study, it can be concluded that MTA exhibited less microleakage when compared to BiodentineTM but BiodentineTM could be used as an alternative material for endodontic treatments. However, further in vitro and in vivo studies should be conducted to determine the sealing ability of BiodentineTM and also establish these results.

\section{Abstract}

Aim: The aim of this study is to evaluate the sealing ability of Biodentine ${ }^{T M}$, which is new calcium-silicate based dental cement and has endodontic indications similar to those of MTA. Methods: The study sample consists of 21 extracted human mandibular anterior teeth. The teeth were submitted to root-end preparation and instrumented up to file \#40 by step back technique and randomly divided into 3 study groups $(n=7)$ : White MTA Angelus ${ }^{\top M}$ (Angelus, Angelus Odontológica, Londrina, PR, Brazil), Biodentine ${ }^{T M}$ (Septodont, SeptodontSpecialités, Saint-MaurdesFosses, France) and the controls. The length of dye penetration between the filling material and tooth structure was measured in millimetres, using a calibrated stereo microscope (Leica MZ75, Germany) at 20 magnification under the same conditions. One-way Analysis of Variance (ANOVA) was used to indicate differences between the experimental groups and the controls. In addition, Tukey Multiple Comparisons Test was used to indicate differences within each group. Results: The results showed that none of the groups were completely sealed. The mean and standard deviation for dye penetration in Biodentine ${ }^{T \mathrm{MM}}$ group was $0.63 \pm 0.20$ and in MTA Angelus ${ }^{\mathrm{TM}}$ group, it was $0.26 \pm 0.25$. Regarding the comparisons between each group, significant differences were not observed $(P=0.0193)$. The comparison between materials only found a significant difference only between MTA Angelus $\mathrm{T}^{\mathrm{TM}}$ and Biodentine ${ }^{\mathrm{TM}}(\mathrm{P}<0.05)$. Conclusions: This study evaluated the possibility of Biodentine ${ }^{T M}$ 's sealing ability and marginal adaptation, since no studies are available on Biodentine. However, further in vitro and in vivo investigations should be conducted to determine the suitability of Biodentine ${ }^{\mathrm{TM}}$ for clinical application.
Received: March 6, 2014

Accepted: May 24, 2014

Address for correspondence

Prof. Dr. Betul Kargul

Marmara University, Dentistry Faculty

Department of Pediatric Dentistry

Buyukciftlik Sok. No:6 K:4

Nisantasi/Istanbul/Turkey

bkargul@marmara.edu.tr

Key words

Tricalcium Silicate; Dental Cements; Dental Leakage; Pulp Capping and Pulpectomy Agents

\section{References}

1. Bernabe PF, Holland R, Morandi R, Souza V, Nery MJ, Otoboni Filho JA et al. Comparative study of MTA and other materials in retrofilling of pulpless dogs' teeth. Braz Dent J. 2005;16:149-55.

2. Bernabé PFE. Healing process after apicotomy and retrofilling. Influence of the material and and root canal conditions: dogs' teeth study [dissertation]. São Paulo: Faculty of Dentistry of Bauru, University of São Paulo; 1981.

3. Vasconcelos BC, Bernardes RA, Duarte MA, Bramante CM, Moraes IG. Apical sealing of root canal fillings performed with five different endodontic sealers: analysis by fluid filtration. 2011 Aug;19(4):324-8.

4. Desai S, Chandler N. Calcium hydroxide-based root canal sealers: a review. J Endod. 2009 Apr;35(4):475-80.

5. Manzano H, Dolado JS, Guerrero A, Ayuela A. Mechanical properties of crystalline calcium-silicate-hydrates: comparison with cementitious C-S-H gels. Physica Status Solidi (A). 2007;204(6):1775-1780.
6. Monteiro Bramante C1, Demarchi AC, de Moraes IG, Bernadineli N, Garcia RB, Spångberg LS et al. Presence of arsenic in different types of MTA and white and gray Portland cement. Oral Surg Oral Med Oral Pathol Oral Radiol Endod. 2008 Dec;106(6):909-13.

7. Bortoluzzi EA, Guerreiro-Tanomaru JM, Tanomaru-Filho M, Duarte MA. Radiographic effect of different radiopacifiers on a potential retrograde filling material. Oral Surg Oral Med Oral Pathol Oral Radiol Endod. 2009 Oct;108(4):628-32.

8. Odler, I. Hydration, setting and hardening of Portland cements. In: Hewlett PC - editor. LEA's Chemistry of Cement and Concrete. $4^{\text {th }}$ edition. Butterworth \& Heinemann: Woburn, Mass, USA; 1998. pp. 241-398.

9. Guo H, Wei J, Yuan Y, Liu C. Development of calcium silicate/calcium phosphate cement for bone regeneration. Biomed Mater. 2007 Sep;2(3):S153-9.

10. Huan Z, Chang J, Huang XH. Self-setting properties and in vitro bioactivity of $\mathrm{Ca} 2 \mathrm{SiO}$ 4/CaSO4-1/2 $\mathrm{H} 2 \mathrm{O}$ composite bone cement. 
J Biomed Mater Res B Appl Biomater. 2008 Nov;87(2):387-94.

11. Ding SJ, Shie MY, Hoshiba T, Kawazoe N, Chen G, Chang HC. Osteogenic differentiation and immune response of human bone-marrow-derived mesenchymal stem cells on injectable calcium-silicate-based bone grafts. Tissue Eng Part A. 2010 Jul;16(7):2343-54.

12. Torabinejad $M$, Parirokh $M$. Mineral trioxide aggregate: a com prehensive literature review-Part II: leakage and biocompatibility investigations. J Endod. 2010 Feb;36(2):190-202.

13. Gandolfi MG, Silvia F, Pashley DH, Gasparotto G, Carlo P. Calcium silicate coating derived from Portland cement as treatment for hypersensitive dentine. J Dent. 2008 Aug;36(8):565-78.

14. Lee SJ, Monsef M, Torabinejad M. Sealing ability of a mineral trioxide aggregate for repair of lateral root perforations. J Endod. 1993 Nov;19(11):541-4.

15. Parirokh M, Torabinejad M. Mineral trioxide aggregate: a comprehensive literature review-Part I: chemical, physical, and antibacterial properties. J Endod. 2010 Jan;36(1):16-27.

16. Parirokh M, Torabinejad M. Mineral trioxide aggregate: a comprehensive literature review-Part III: clinical applications, drawbacks, and mechanism of action J Endod. 2010 Mar;36(3):40013.

17. Duarte MAH, Demarchi ACCO, Yamashita JC, Kuga MC, Fraga SC. $\mathrm{pH}$ and calcium íon release of 2 root-end filling materials. Oral Surg Oral Med Oral Pathol Oral Radiol Endod. 2003 Mar;95(3):345-7.

18. Holland R, Souza V, Nery MJ, Fáraco Júnior IM, Bernabé PFE, Otoboni Filho JA et al. Reaction of rat connective tissue to implanted dentin tube filled with mineral trioxide aggregate, Portland cement or calcium hydroxide. Braz Dent J. 2001;12(1):3-8.

19. Laurent P, Camps J, De Méo M, Déjou J, About I. Induction of specific cell responses to a $\mathrm{Ca} 3 \mathrm{SiO} 5$-based posterior restorative material. Dent Mater. 2008 Nov;24(11):1486-94.

20. Han L, Okiji T. Uptake of calcium and silicon released from calci um silicate-based endodontic materials into root canal dentine. Int Endod J. 2011 Dec;44(12):1081-7.

21. Asgary S, Shahabi S, Jafarzadeh T, Amini S, Kheirieh S. The properties of a new endodontic material. J Endod. 2008 Aug;34(8):9903.

22. Gomes-Filho JE, Rodrigues G, Watanabe S Evaluation of the tis sue reaction to fast endodontic cement (CER) and Angelus MTA. Endod. 2009 Oct;35(10):1377-80.

23. Goldberg, M; Pradelle-Plasse, N; Tran, X. Emerging trends in (bio) material researches. In: Goldberg, M - editor. Biocompatibility or cytotoxic effects of dental composites. Oxford, UK: Coxmoor Publishing; 2009. p. 181-203.

24. Raskin A, Eschrich G, Dejou J, About I. In Vitro Microleakage of Biodentine as a Dentin Substitute Compared to Fuji II LC in Cervical Lining Restorations J Adhes Dent. 2012 Dec;14(6):535-42.

25. Koubi S, Elmerini H, Koubi G, Tassery H, Camps J. Quantitative evaluation by glucose diffusion of microleakage in aged calcium silicate-based open-sandwich restorations. Int J Dent. 2012;2012:105863.

26. Grech L, Mallia B, Camilleri J. Investigation of the physical properties of tricalcium silicate cement-based root-end filling materials. Dent Mater. 2013 Feb;29(2):e20-8.

27. Lin S, Platner O, Metzger Z, Tsesis I. Residual bacteria in root apices removed by a diagonal root-end resection: a histopathological evaluation. Int Endod J. 2008 Jun;41(6):469-75.

28. Post LK, Lima FG, Xavier CB, Demarco FF, Gerhardt-Oliveira M. Sealing ability of MTA and amalgam in different root-end preparations and resection bevel angles: an in vitro evaluation using marginal dye leakage. Braz Dent J. 2010;21(5):416-9.

29. Verıssimo DM, do Vale MS. Methodologies for assessment of apical and coronal leakage of endodontic filling materials: a critical review. J Oral Sci. 2006 Sep;48(3):93-8.
30. Souza EM, Pappen FG, Shemesh H, Bonanato-Estrela C, BonettiFilho I.Reliability of assessing dye penetration along root canal fillings using methylene blue. Aust Endod J. 2009 Dec;35(3):158 63.

31. Derkson GD, Pashley DH, Derkson ME. Microleakage measurement of selected restorative materials: a new in vitro method. Prosthet Dent. 1986 Oct;56(4):435-40.

32. Wu MK, Kontakiotis EG, Wesselink PR. Decoloration of $1 \%$ methylene blue solution in contact with dental filling materials. J Dent. 1998 Sep;26(7):585-9.

33. Moraes IG, Moraes FG, Mori GG, Gonçalves SB. Influence of calciumhydroxide on dyes for dentin labeling, anlyzed by means of a new methodology. J Appl Oral Sci. 2005 Sep;13(3):218-21.

34. Tanomaru Filho M, Figueiredo FA, Tanomaru JM. Effect of different dye solutions on the evaluation of the sealing ability of Mineral Trioxide Aggregate. Braz Oral Res. 2005 Apr-Jun;19(2):119-22.

35. Stefopoulos S, Tsatsas DV, Kerezoudis NP, Eliades G. Comparative in vitro study of the sealing efficiency of white vs grey ProRoot mineral trioxide aggregate formulas as apical barriers. Dent Traumatol. 2008 Apr;24(2):207-13.

36. Shahi S, Yavari HR, Rahimi S, Eskandarinezhad M, Shakouei S, Unchi M. Comparison of the sealing ability of mineral trioxide aggregate and Portland cement used as rootend filling materials. Oral Sci. 2011 Dec;53(4):517-22.

37. Caicedo R, Von Fraunhofer JA. The properties of endodontic sealer cements. J Endod. 1988 Nov;14(11):527-34.

38. SilvaNeto UX, Moraes IG. Sealing capacity produced by some materials when utilized under furcation perforations of extract human molars. J Appl Oral Sci. 2003 Mar;11(1):27-33.

39. Al-Hezaimi K, Naghshbandi J, Oglesby S, Simon JH, Rotstein I. Human saliva penetration of root canals obturated with two types of mineral trioxide aggregate cements. J Endod. 2005 Jun;31(6):453-6.

40. Bortoluzzi EA, Broon NJ, Bramante CM, Garcia RB, de Moraes IG, Bernardineli N. Sealing ability of MTA and radiopaque Portland cement with or without calcium chloride for root-end filling. J Endod. 2006 Sep;32(9):897-900.

41. De Bruyne MA, De Bruyne RJ, De Moor RJ. Long-term assessment of the seal provided by root-end filling materials in large cavities through capillary flow porometry. Int Endod J. 2006 Jun;39(6):493-501.

42. Hamad HA, Tordik PA, McClanahan SB. Furcation perforation repair comparing gray and white MTA: a dye extraction study. J Endod. 2006 Apr;32(4):337-40.

43. Sarkar NK, Caicedo R, Ritwik P, Moiseyeva R, Kawashima I. Physicochemical basis of the biologic properties of mineral trioxide aggregate. J Endod. 2005 Feb;31(2):97-100.

44. Tay FR, Pashley DH, Rueggeberg FA, Loushine RJ, Weller RN. Calcium phosphate phase transformation produced by the interaction of the portland cement component of white mineral trioxide aggregate with a phosphate- containing fluid. J Endod. 2007 Nov;33(11):1347-51.

45. Leal F, De-Deus G, Brandão C, Luna AS, Fidel SR, Souza EM. Comparison of the root-end seal provided by bioceramic repair cements and White MTA. Int Endod J. 2011 Jul;44(7):662-8.

46. Pellenq RJM, Kushima A, Shahsavari R, Van Vliet KJ, Buehler MJ, Yip S et al. A realistic molecular model of cement hydrates. Proc Natl Acad Sci U S A. 2009 Sep 22;106(38):16102-7.

47. Lenander-Lumikari $M$, Loimaranta V. Saliva and dental caries. Adv Dent Res. 2000 Dec;14:40-7

48. Gandolfi MG, Van Landuyt K, Taddei P, Modena E, Van Meerbeek $B$, Prati C. Environmental scanning electron microscopy connected with energy dispersive X-ray analysis and Raman techniques to study proroot mineral trioxide aggregate and calcium silicate cements in wet conditions and in real time. J Endod. 2010 May;36(5):851-7. 